\title{
ARTIKELEN
}

\section{Inheemse conflictbeslechting in Suriname}

\section{Een antropologie van herstelrecht}

\author{
Makiri Mual
}

Sinds januari 2020 loopt een twee jaar durend Twinning-onderzoek naar de strafrechtspraktijk in Suriname. ${ }^{1}$ De focus is tweeërlei: enerzijds onderzoek naar de formele strafrechtspleging met als kapstok de Surinaamse wetboeken en anderzijds onderzoek naar lokale geschilbeslechting bij zowel de Marrongemeenschap als de inheemse gemeenschap. Suriname wordt bevolkt door veel verschillende bevolkingsgroepen. De onderzochte groepen waren de nazaten van de weggelopen slaven, de Marrons en de Inheemsen, een verzamelnaam voor een aantal autochtone indianenstammen.

Dit artikel beschrijft de contouren van de rechtspraktijk van de Inheemsen. Het doet verslag van een zoektocht naar vormen van herstelrecht in de binnenlanden van Suriname (zie ook Claessen \& Djokarto, 2020). Daarbij worden zowel bestaande rechtsetnografische studies benut als voorlopige bevindingen in het kader van het Twinning-onderzoek. Met behulp van vragenlijsten, afgenomen in vier lokale gemeenschappen, beogen de Twinning-onderzoekers een beeld te krijgen van de wijze waarop delicten worden afgedaan binnen de inheemse gemeenschap. ${ }^{2}$ Vooruitlopend op de verificatie van het ruwe onderzoeksmateriaal door de ondervraagden biedt dit artikel een voorlopig verslag van (eigen) bevindingen opgedaan tijdens bezoeken aan gemeenschappen van Cariben, Arowakken en Wayana.

\section{Context en verantwoording van het onderzoek}

Het onderzoek vergde bijzondere voorbereiding vanwege de achterdocht die bij de Inheemsen leeft voor westerse onderzoekers. Een passend onderzoekskader werd gevonden in de Free and prior informed consent (FPIC), waarbij het object van onderzoek, de inheemse gemeenschap, vanaf aanvang meedenkt en te allen tijde een veto kan uitspreken. De FPIC-werkwijze is ontstaan om onethische praktijken tegen te gaan waarbij onderzoekers van buiten de inheemse gebieden waardevolle kennis vergaarden zonder medeweten van de lokale bevolking. Doel van de

1 De Twinning-partners zijn: Jacques Claessen voor de Universiteit van Maastricht, Makiri Mual en Theo de Roos voor Restorative Justice Nederland, Alrik de Haas voor Stichting Mens en Recht voor Nederland en de Surinaamse partners Anton de Kom Universiteit Stichting vertegenwoordigd door Rinette Djokarto, Renzo Duin van ESAV voor de Inheemsen en Ellen Braam voor de stichting River of Jordan die de Marron gemeenschap vertegenwoordigt.

2 De etnische origine van de stammen waren Carib (Pierre Kondre Kumbassi), Carib/Arowak (Powakka), Matta (Arowak) en Wayana (Kawemhakan). 
FPIC-werkwijze is de bij inheemse volkeren levende gedachte te bestrijden dat westerse onderzoekers de lokale bevolking bewust onwetend houden en het profijt niet delen. ${ }^{3}$ Een vergelijkbare, en door ons toegepaste benadering ligt in het principe van Access and Benefit Sharing (ABS), dat vorm kreeg via aan de betrokken inheemse gemeenschappen geleverde (en te leveren) onderzoeksresultaten in de vorm van verslagen, artikelen, onderwijsprogramma's en andere vormen van deskundigheidsbevordering, zoals workshops en trainingen aan medewerkers in de formele en informele strafrechtspraktijk (Kirchner, 2015). Daarmee voldoet de opzet van het onderzoek naar herstelrecht tevens aan het binnen de Twinning vereiste criterium van duurzaamheid.

Vertrekpunt van het onderzoek was dat een strafbaar feit en de (gewoonterechtelijke) reactie daarop moeten worden begrepen vanuit de culturele context waarin het wordt gepleegd en wordt afgedaan. Traditionele rechtspleging brengt zowel het strafrechtelijk vertoog als ook de sociale opvattingen van het inheemse volk tot uitdrukking. De eerste fase van het onderzoek beoogde een inventarisatie van de rechtspleging te maken door middel van semigestructureerde interviews met vragen over het delict, de bewijsvoering, sancties, strafuitsluitingsgronden, documentatie en emoties. Om de vragenlijst begrijpelijk te maken voor de ondervraagden werd deze vertaald in het Sranang en Arowaks. Een lokale projectpartner zorgde voor de voorbereiding en toezending van de vragenlijsten aan de gezagsdrager van de dorpen, meestal de kapitein of de granman. ${ }^{4}$ De kapitein en zijn assistent (basja) zorgden vervolgens voor de respondenten, die voornamelijk bestonden uit ouderen, zowel mannen als vrouwen, die konden vertellen over gewoonterecht inzake misdaad in verleden en heden. De respondenten vertegenwoordigden drie inheemse dorpen in de provincie Para (Pierre Kondre Kumbassi, Powakka en Matta) en een in de Sipaliwini (Kawemhakan).

\section{Surinaamse rechtssystemen in historisch perspectief}

Suriname kent al eeuwen verschillende (informele) rechtssystemen die naast elkaar functioneren. Het gezag ten tijde van de slavernij berustte zowel bij het gouvernement in Paramaribo als bij de plantagehouders in een vorm van 'huiselijke jurisdictie'. De plantagehouders hadden de vrije hand en konden optreden als rechter. Dat ook niet strafbare feiten werden bestraft, viel binnen de vrijheid van de plantagehouders, die zich regelmatig aan wreedheden te buiten gingen, zoals de

3 De interesse van farmaceuten voor geneeskrachtige planten en natuurgeneeswijzen is daarvan een bekend voorbeeld.

4 In tegenstelling tot de Marrongemeenschappen die wel over een dorpoverstijgende autoriteit beschikken (bijv. Granman Aboikoni van de Djuka of de Saramakaners) heeft ieder inheems dorp zijn eigen granman of kapitein. De handhaving van orde en veiligheid blijft daarmee een lokale aangelegenheid en er kan alleen strafrechtelijk worden 'opgeschaald' naar het centraal gezag. Anno nu zijn 10 van 52 kapiteins vrouw, zoals ook in Powakka tijdens het onderzoek in 2020. Informatie over het traditionele inheemse gezag: www.vids.sr. 
Spaanse bok, ${ }^{5}$ geseling tot de dood erop volgt of eigenstandige onthoofding (Wijnholt, 1965). Slechts in 'ernstige gevallen' werd de plantagehouder gekapitteld. Oudayraisingh Varma bestudeerde de 'huislijke rechtspraak' en haalt het plakkaat van Gouverneur Van Sommelsdijck (1683-1688) aan, waarin hij had bepaald dat een meester zijn slaaf niet eigenmachtig mocht verminken of doden, maar in de praktijk kwam daar weinig van terecht. Hoewel het origineel van die verordening niet meer is teruggevonden, maakt Hartsinck daar in zijn publicatie 'Beschryving van Guiana, of de wilde kust in Zuid-America' gewag van (Hartsinck, 1770). Het boek Geschiedenis van Suriname van de hand van Wolbers beschrijft de vele misstanden en een enkele klacht van drie tot slaaf gemaakten die een zekere Tuymelaar aanklaagden vanwege slechte en wrede behandeling. De klachten werden door Justitie gehoord en 'hoewel 'die klagten niet ten eenemale buiten rede en fondament waren', besloot Justitie de klagers toch te geselen omdat 'er wel pykanterie onder zou schuylen' (Wolbers, 1861: 132).

Aan deze praktijk van privérechtspraak kwam formeel een einde in 1851 met de inwerkingtreding van het 'Reglement op de behandeling van de slaven', enkele jaren voor de daadwerkelijke afschaffing van de slavernij in 1873. Naast dit 'koloniale strafrecht' hebben altijd lokale vormen van afdoening van geschillen bestaan, met name in de ver buiten de reikwijdte van het centrale gezag gelegen binnenlandse gebieden. Het overgrote deel van Suriname had daardoor te maken met aan lokale kapiteins en granmans overgedragen rechtsmacht. De benoeming van de lokaal gekozen kapitein of granman werd door het centraal gezag naderhand geratificeerd met een officieel document en versierselen, waaronder een uniform. Zij combineerden dat mandaat met lokaal gewoonterecht. In de praktijk gold dan ook alleen voor Paramaribo en de kuststreek van Nieuw Nickerie tot aan Albina het centrale gezag, waarnaast incidenteel door gezanten van het gouvernement rechtszittingen werden gehouden in het binnenland (Bemmel, 1972).

Sinds de zeventiende eeuw maakte het gouvernement onderscheid tussen de Inheemsen en de Marrons. De Marrons vielen onder de slavenwetgeving van het centrale gezag en de 'huiselijkse jurisdictie'. De Inheemsen vielen daarbuiten, omdat zij zich niet tot slaaf lieten maken. Bovendien collaboreerden de Inheemsen met het gouvernement om weggelopen slaven op te sporen. Ondanks die samenwerking raakten de Inheemsen in conflict met het gezag. Het vredesverdrag dat na decennia van vijandigheden in 1868 werd gesloten tussen de Inheemsen en het centraal gezag verschafte de Inheemsen een bijzondere positie. Hun traditionele rechtspraak werd grotendeels ongemoeid gelaten, met uitzondering van rechtspleging inzake doodslag en het uitspreken van de doodstraf (Wijnholt, 1965: 8).

Gevolg van het vredesverdrag was dat de Arawakken, de Cariben en de Warau's 'als vrije stammen werden erkend en hen werd toegestaan volgens hun eigen wetten en gewoonten te leven. (...) en dat zij geheel in het genot van hun eigen recht en rechtspraak zijn gelaten' (Wijnholt, 1965: 7). De Marrons hebben hun traditionele strafwetten onlangs in ere hersteld door het opstellen van de Twaalf Wetten. Zo hebben

5 Spaanse Bok is de benaming voor een wrede lijfstraf waarbij men de handen samenbond; daarna wrong men de knieën tussen de samengebonden handen en stak dan een stok tussen de handen en de opgetrokken knieën. De stok werd stevig in de grond bevestigd. 
de Aucaners hun wijze van geschilbeslechting door middel van benoeming van het delict en de bestraffing vastgelegd. ${ }^{6}$

Formeel is echter voor heel Suriname, dus ook voor de binnenlanden, het statelijk strafrecht van toepassing. De Surinaamse rechtspraak lijkt dan ook een 'rommelig geheel' te zijn geworden van koloniale rechtspraak, huiselijke jurisdictie, slavenrecht, plantagerecht, onmachtige handhaving en bestaand lokaal gewoonterecht met als uiteindelijk resultaat een postkoloniaal strafrecht geënt op het Nederlandse Wetboek van Strafrecht en het Wetboek van Strafvordering. Deze postkoloniale strafrechtspleging is feitelijk wezensvreemd voor Surinames multiculturele inwoners (Javanen, Creolen, Marrons, Hindoestanen, Libanezen, Joden en de Inheemsen). In het binnenland worden de lokale hoofden dan ook traditiegetrouw nog steeds gekozen uit de eigen gelederen. En hoewel zij worden ingezworen als vertegenwoordiger van het centraal gezag en verantwoordelijk zijn voor de openbare orde, handhaving en burgerzaken, staan zij met één been in de traditionele en met het andere in de formele strafrechtspleging.

De Inheemsen geven blijk van een uitgesproken belangstelling voor herstelrechtelijke interventies, waarbij eigen inheemse praktijken worden gecombineerd met restorative justice-praktijken van buiten. Onze respondenten geven aan veel herstelgerichte elementen te herkennen in hun eigen gewoonten, waaronder het afwijzen van vrijheidsstraffen en vooral de aandacht voor de rol van de gemeenschap bij sanctionering en naleving. Buitensluiten is voor Inheemsen namelijk erger dan de doodstraf. Om de door ons gevonden overeenkomsten tussen de traditionele (straf)rechtspleging en herstelgerichte praktijken (zie par. 5) helder te kunnen duiden, gaan we eerst dieper in op de kenmerken van inheemse strafrechtspleging zoals beschreven in (rechts)historisch en antropologisch onderzoek.

\section{Onderzoek naar inheemse (straf)rechtspleging}

\subsection{Nederlands onderzoek}

Over (straf)rechtspleging bij Inheemsen is vanuit rechtshistorisch perspectief weinig geschreven. In achttiende- en negentiende-eeuwse etnografische verhandelingen en expeditieverslagen zijn enkele observaties vindbaar over conflicten en de gewoonterechtelijke reactie van de gemeenschap daarop. ${ }^{7}$ De meest voorkomende vorm van beslechting was de krutu (de dorpsvergadering), ook wel 'eindeloos palaveren' (praten tot er overeenstemming is bereikt). Naar dit fenomeen noch naar

6 Deng weti fu a twalufu Lo Gaanmang meke tien na dii fu okanisie (Velanti et al., 2017). Behalve delicten bestrijkt het wetboek tevens gedragsregels die te maken hebben met teraardebestelling en andere zaken. De sancties bestaan voornamelijk uit schadevergoeding, meestal in de vorm van eenheden alcoholische dranken. De Aukaner wetten zijn meer een verzameling gedragsaanwijzingen met sancties bij overtreding dan een gestructureerd wetboek. Het geheel beslaat nog geen twintig pagina's. De betekenis van de 'Deng Weti' is meer gelegen in de herwaardering van de eigen cultuur door het documenteren van Aukaner zeden en gewoonten.

7 De Nederlandse overheid hechtte destijds aan een goede beschrijving van Suriname, te beginnen met het vaststellen van de landsgrenzen en de cartografie. Geen van de expedities had echter een etnografisch doel. Niettemin werden talloze inheemse artefacten naar Nederland gezonden ten behoeve van het KIT en het tegenwoordige Wereldmuseum. Verslagen van deze expedities zijn verschenen als KNAG-verslag. 
andere vormen van geschilbeslechting is tot op heden fundamenteel onderzoek gedaan. Tot 1950 vallen enkele volkenkundige studies op. Zo doet Abbenhuis verslag van een bezoek aan het dorp Matta (provincie Para) in de jaren dertig (Abbenhuis, 1940). Het onderzoeksverslag bevat echter slechts losse observaties over delicten en straf, wat is terug te voeren op de cartografische en geologische insteek van deze expedities. ${ }^{8}$ Desondanks bieden deze - en andere vergelijkbare - verslagen behalve een beschrijving van casuïstiek ook observaties over rechtspleging bij de Inheemsen in het licht van de destijds geldende couleur locale. ${ }^{9}$

De tweede helft van de vorige eeuw blijkt rijker aan wetenschappelijke publicaties over de inheemse (straf)rechtspleging. De jurist Wijnholt noemt in zijn dissertatie de ontbrekende kennis over geschilbeslechting bij Marrons en Inheemsen een groot gemis. Hij concludeert dat kennis van traditionele vormen van geschilbeslechting onontbeerlijk is voor een deugdelijke werking van de strafrechtspleging in een land met zoveel culturele verschillen als Suriname (Wijnholt, 1965: 5).

Vanaf de jaren zeventig neemt de wetenschappelijke belangstelling voor de rechtspleging bij de Inheemsen in Nederland toe. Zo verbleef de antropoloog Peter Kloos in die periode enkele jaren in Galibi aan de Marowijnerivier. Hij schreef onder meer over conflicten en de inspanningen die de gemeenschap zich getroostte om de harmonie te bewaren. De jurist Bemmel legde destijds in diens dissertatie de rechtspleging onder de Indianen onder de loep (Bemmel, 1972). Hij maakt als eerste het onderscheid tussen leedtoevoeging en verzoening (herstel). ${ }^{10}$ Ten slotte kreeg Suriname met de studie van Pronk haar eerste echte criminologische 'overzichtswerk', waarin de Inheemsen overigens geheel ontbreken. Een studie van latere datum is die van antropologe Karin Boven, die enkele jaren in Kawemhakan (provincie Sipaliwini) verbleef en promoveerde op de cultuur en gebruiken van de Wayana (Boven, 2006). ${ }^{11}$ Over conflicthantering is door haar weinig meer vastgelegd dan de opvatting dat (ook) de Wayana's het liefst het conflict mijden en dat de gezagsdragers, vooral primus inter paris, slechts worden geaccepteerd dankzij eigen voorbeeldig gedrag. Politiek gezag dus, zonder exclusieve macht over geweldsmiddelen. De antropoloog André Köbben constateerde dat hetzelfde delict vanuit het centraal gezag en het lokale gewoonterecht verschillend worden geïnterpreteerd en dus ook verschillend worden bestraft. ${ }^{12}$ Ook merkte hij op dat de lokale gezagsdragers weinig traditionele rechtsmacht hadden en dat ze daardoor vaak met lege handen stonden. Een constatering die ook opgaat in het huidige tijdsgewricht.

8 Het dorp Matta is ook in ons onderzoek betrokken.

9 In de eerste helft van de twintigste eeuw droegen de onderzoekers en met name C. De Goeje en pater W. Ahlbrinck met etnografische beschrijvingen bij aan kennis van de sociale structuur van de Inheemsen.

10 Andere onderzoekers, zoals F. Oedayarajsingh Varma (1977), bogen zich in deze jaren over het koloniale strafrecht rond de achttiende eeuw; Ruud Beeldsnijder promoveerde in 1994 op rechtspleging ten tijde van de slavernij tussen 1730 en 1750 (Beeldsnijder, 1994).

11 Zij deed dat op klassiek antropologische wijze met aandacht voor de genealogie en de sociaal-politieke structuur.

12 Köbben onderzocht net als Kloos de Djoeka-gemeenschappen in Suriname (vermeld in: Brunt, 2021). 


\subsection{Een conflictvermijdende volksaard}

Wat betreft de inheemse (straf)rechtspleging in Suriname is het onderzoek van Kloos over rechtspleging bij de Cariben, een van de inheemse volken van Suriname, van belang. Het is de eerste studie naar conflicten en strafrechtspleging in Suriname. Kloos beschrijft misdaden die in de jaren vijftig en zestig van de vorige eeuw werden afgedaan in Suriname. Dat was een belangrijk tijdsgewricht, omdat traditionele en hedendaagse (staats)rechtspleging toen al regelmatig met elkaar in botsing kwamen (Kloos, 1969). Hij verwondert zich over de wijze waarop de Cariben zich verhouden tot conflicten en misdaad (Kloos, 1971: 188-208). Hij meent dat de conflictvermijdende volksaard te maken heeft met de sociaal-politieke en verwantschapsstructuren. Het inheemse individu wordt aangemoedigd door kernwaarden die ook bij de opvoeding van de indianen werden gesignaleerd, zoals onafhankelijkheid, zelfvertrouwen, afwezigheid van agressief gedrag en emotionele afzijdigheid. Kloos is niet de enige onderzoeker die de onaangedane persoonlijkheid van de indiaan opvalt. Ook in andere studies en expeditieverslagen uit de negentiende en eerste helft van de twintigste eeuw wordt melding gemaakt van de flegmatieke wijze waarop de indianen met (eigen) gekwetstheid en misdaden omgaan (Kloos, 1975: 64). Agressief gedrag wordt binnen deze inheemse cultuur in beginsel afgewezen en vermeden. In Galibi, waar Kloos twee jaar verbleef, vormde agressief gedrag tijdens Casiri-feesten voor jongens zelfs een handicap om een vrouw te krijgen. ${ }^{13}$ Cariben vrouwen zouden de voorkeur geven aan rustige, timide mannen.

Er lijkt voorts een verband te zijn met hun beperkte onderlinge economische afhankelijkheid; de indianen hebben dezelfde economische belangen en hebben elkaar daarvoor nauwelijks nodig. Er is geen schaarste aan kostgronden en allianties worden alleen gevormd om het ontginningswerk met elkaar te doen. ${ }^{14}$ Deze beperkte afhankelijkheid zou geen aanleiding geven tot conflicten, mede omdat de natuurlijke hulpbronnen toebehoren aan de gemeenschap en er geen privébezit is. Exclusief recht op een natuurlijke hulpbron ontstaat pas door een kostgrond te bewerken en in gebruik te nemen door wieden, zaaien, beplanting en bebouwing met een huis. Met andere woorden, door ingebruikneming ontstaat tijdelijk individueel eigendomsrecht dat vervalt wanneer de kostgronden worden verlaten of wanneer de oogst niet meer wordt binnengehaald. Zaken die door mensenhanden zijn gemaakt, zoals korjalen en gereedschappen, zijn privé-eigendom, maar dienen binnen de eigen clan te worden uitgeleend zolang ze niet in gebruik zijn door de eigenaar. Kloos brengt dit in verband met de constatering dat diefstal nauwelijks voorkomt, zelfs niet in gevallen van schaarste (Kloos, 1975).

Ook andere onderzoekers constateerden dat misdaden zoals diefstal, geweld en oplichting nauwelijks voorkomen binnen de inheemse gemeenschappen (Bemmel, 1972; Hurault, 1968). Echter, volgens Bemmel kwamen wraakneming en moord in vroeger tijden veel voor, met name gericht tegen niet-stamgenoten. Die levensdelicten vloeiden volgens hem voort uit spanning tussen clans en volkeren en waren vooral het gevolg van vergeldingsacties. Geweld naar eigen stamgenoten lag an-

14 Ieder inheems gezin heeft een kostgrond elders in het woud, waarop bittere casave en andere levensmiddelen worden verbouwd. De kostgronden zijn communaal bezit en het gezin heeft daarvan vruchtgebruik. 
ders. 'Het besef toch, dat wraak binnen de stam de kracht van de eigen gemeenschap te zeer verzwakte, moeten de primitieven al heel lang hebben gehad' (Bemmel, 1972: 18). Andere misdaden, zoals moord, incest, overspel (niet bij alle stammen), verraad of vergrijpen tegen religie of bepaalde taboes werden vanuit het gewoonterecht hoog opgenomen, maar van recente eigenrichting en wraakneming zijn geen schriftelijke bronnen beschikbaar. ${ }^{15}$ De reactie op ernstige misdaden leidde feitelijk tot 'vrijwillig' vertrek van de persoon in kwestie, alleen of met familie. Aan de strafoplegging ging een familie- of dorpsberaad ( $k r u t u)$ vooraf. Was de straf aanvaardbaar voor de overtreder, dan werd die straf ondergaan. Was de schaamte te groot, dan was vertrek de enige optie. Het herstel van het evenwicht in de gemeenschap werd dus bereikt doordat de overtreder het dorp verliet, zelfgekozen verbanning als ultimum remedium. Latere studies bevestigen de observatie van Kloos dat dergelijke zware misdaden en de bijbehorende ultieme bestraffing van de verbanning al decennia niet meer voorkomen. Ook de door ons recent gevoerde vraaggesprekken bevestigen dit.

Samengevat levert Nederlands onderzoek naar de stafrechtspleging in Suriname in de twintigste eeuw een tamelijk incompleet en gefragmenteerd beeld op, waarbij behalve de onderlinge samenhang ook het verband met het centraal gezag ontbreekt. Bieden vergelijkbare, vooral klassieke etnografische onderzoeken meer zicht op hoe recht wordt gedaan in inheemse gemeenschappen?

\subsection{Enkele klassieke rechtsetnografische bevindingen}

Sommige klassieke antropologische studies bieden in een aantal opzichten een steviger fundament voor onderzoek naar de (straf)rechtspleging bij inheemse gemeenschappen, mogelijk ook die van Suriname. In 1926 ageerde Malinowski al tegen de toentertijd heersende, geromantiseerde opvattingen over de 'nobele wilde'. Het beeld als zouden Inheemsen zich blijmoedig voegen in de groepsdynamiek en zich als van nature ondergeschikt maken aan de gemeenschap, wordt door hem bekritiseerd. Hij verzette zich tegen de stelling dat 'primitieve' samenlevingen geen (geschreven) rechtssysteem zouden hebben, waardoor inheemse rechtspleging niet eenduidig zou zijn en blijk geven van willekeur, want afhankelijk zijn van 'persoonlijke, familiale en clanbelangen'. Het beeld van de 'altruïstische, nobele wilde' ontkrachtend, stelde Malinowski dat ook voor de 'primitieve samenleving' geldt dat de mens zelfgericht is en, als het even kan, zich aan de groepsdruk onttrekt. De savage society doet in dat opzicht niet onder voor de moderne westerse samenleving (Malinowski, 1926).

De groeiende belangstelling voor sociaal-politieke onderwerpen als macht en recht onder twintigste-eeuwse antropologen leidde tot een subspecialisatie over recht en handhaving in ongerepte gemeenschappen. Die discipline is anthropology of law gaan heten, ook wel rechtsetnografie genoemd. Tot de vroegste studies behoort The Law of Primitive Man van Hoebel, waarin hij het denkkader uitwerkt over recht en de verplichtingen die dat meebrengt. Op basis van casestudies bij Noord-Amerizoekers als Ahlbrinck en De Goeje, maar ook Kloos signaleerde dat. 
kaanse indianen en inheemse gemeenschappen in Afrika duidt hij begrippen als schuld, verplichting en reciprociteit en constateert dat de Inheemsen sterk geneigd zijn om geschillen in het civiele domein te houden, totdat het niet langer kan (Hoebel, 1954). Belangrijke antropologische inzichten zijn voorts te vinden in het onderzoek van Leopold Pospisil. Zijn studie naar conflicthantering bij de Kapauku in het toenmalige Nederlands Nieuw-Guinea heeft betrekking op 165 delicten en doet verslag van de wijze waarop de gemeenschap daarop heeft gereageerd (Pospisil, 1967). ${ }^{16}$

Beide studies, die van Hoebel en Pospisil, laten zich lezen als een onderzoek naar herstelgericht straffen op communaal niveau, in die zin dat het evenwicht in de lokale gemeenschap zo spoedig mogelijk moet worden hersteld. Het zwaartepunt ligt op het herstel van orde en rust in de gemeenschap; daaraan lijkt het individuele aspect ondergeschikt te zijn. Daarnaast valt een tweede aspect op, namelijk dat genoegdoening naast een materiële kant, ook een immateriële waarde vertegenwoordigt. Dat aspect komt tot uitdrukking in begrippen als schadevergoeding, zoenoffer en dergelijke die binnen de inheemse (straf)rechtspleging worden gehanteerd. Voorts heeft het rituele of ceremoniële afsluiten een belangrijke psychologische functie binnen de lokale gemeenschappen: het herstelritueel markeert de cohesie en veerkracht van de gemeenschap. Ten slotte is de voortvarendheid kenmerkend; er wordt direct aan vergelijk, genoegdoening en herstel gewerkt, met directe uitkomsten en het terstond inlossen van schuld. Aanhoudende spanning tussen slachtoffer en dader en hun omgeving (gezin, familie, clan en dorp) zou te bedreigend zijn voor de gemeenschap. Opvallend is ook dat de herstelbijeenkomsten zo lang duren als nodig.

\section{Tegenwoordige inheemse (straf)rechtspleging}

In deze paragraaf geven we beknopt aan hoe de kapitein tegenwoordig recht spreekt en op welke delicten wordt gereageerd. Om met dat laatste te beginnen, afgaande op de hiervoor besproken literatuur is mishandeling de meest voorkomende misdaad bij de Inheemsen, meestal ontstaan tijdens de drinkgelagen. Bijvoorbeeld, wanneer een persoon tijdens een Casiri-feest ${ }^{17}$ wordt beschimpt of dreigt te worden mishandeld, zal de familie van de agressieve partij proberen kwetsend gedrag te voorkomen. Mocht het bij woorden blijven, dan worden de gemoederen getemperd door het maken van grappen, waarmee de spanning wordt gereguleerd. Een

16 Pospisils beschrijving van delicten betrof geweldsdelicten als (poging tot) mishandeling, poging tot suïcide, hekserij, liegen, onderhouden ongeoorloofde (seksuele) relaties, incest, overspel, diefstal, vernieling, huisvredebreuk, bedrog en misleiding, maar ook niet-nakoming van afspraken en belediging van hoogwaardigheidsbekleders. Bij de Kapauku valt vooral de veelheid aan misdaden op die te maken hebben met stammenoorlogen, zoals verraad, spionage en beschamen van de clan door desertie (Pospisil, 1967).

17 Ter voorbereiding van een Casiri-feest worden grote hoeveelheden alcoholhoudende Casiri gemaakt die, soms over meerdere dagen verspreid, wordt gedronken door mannen en vrouwen. Men drinkt door tot overgevens toe om vervolgens weer door te drinken. Verreweg de meeste geweldsdelicten vinden dan plaats. Opmerkelijk dat daarvan nauwelijks melding wordt gemaakt bij het centrale gezag, behalve als ziekenhuisbezoek nodig is, bijvoorbeeld doordat een ruzie met kapmessen is uitgevochten. 
paar klappen over en weer hoort bij het Casiri-feest. Dat beschouwt de indiaan als normaal en opluchtend. Is er (blijvend) letsel of zijn vrouwen of kinderen het slachtoffer, dan gaat dat een grens over en vindt de volgende dag in alle vroegte een volksvergadering plaats onder leiding van de basja, kapitein of granman.

Aan de hand van de misdaad bepaalt de kapitein of de kwestie van publiek belang is of niet. Mocht het een misdrijf betreffen in de huiselijke kring (huiselijk geweld of burengeschillen), dan wordt een besloten bijeenkomst gehouden, met een vooraanstaande rol voor de familie van de benadeelde(n). In alle andere gevallen participeren de dorpsbewoners aan de krutu. Slachtoffer en verdachte worden gehoord, evenals getuigen, en de kapitein bemiddelt op 'zachte wijze' totdat een vergelijk is bereikt. Die overeenstemming kan bestaan uit het maken en ontvangen van verontschuldigingen en het vergoeden van geleden schade. De uitkomst van deze $\mathrm{kru}$ tu wordt, zoals de ongeschreven regel voorschrijft, niet betwist. De 'schuldige(n)' draagt (dragen), het gemeenschappelijk bereikte oordeel op gelaten wijze, ook wanneer over het bemiddelingsresultaat gemengde gevoelens bestaan. Er is derhalve geen mogelijkheid tot 'beroep'.

\subsection{Herstelgerichte interventies}

De kapitein benut vooral herstelgerichte interventies, oplopend van praten en dreigen tot straffen of uiteindelijk doorverwijzen naar het centraal gezag in de stad (politie). Naast schadevergoeding is een contactverbod de meest opgelegde straf. De kapitein probeert door het tijdelijk contactverbod de gelederen gesloten te houden en partijen de kans te geven om tot bedaren te komen. Een (vrijheids)straf of geseling zou de onderlinge spanningen tussen individuen alleen maar kunnen doen oplopen. Families en clans zouden daarbij betrokken raken, waardoor rust, orde en vreedzame co-existentie in het dorp in het geding komen. Als het negeren permanent wordt, dan vertrekt de genegeerde met zijn gezin naar een ander dorp (Kloos, 1975). Door het gebrek aan een uitgewerkt rechts- en handhavingssysteem is vermijding of zelfgekozen verbanning bij hevige conflicten de enige oplossing: 'In the absence of specific mechanisms for conflict resolution, separation is the only effective measure that can be taken in Carib society to prevent continuous conflict.' (Kloos, 1975: 207).

Over de rechtsmacht van de kapitein melden de antropologen Kloos en Boven dat deze feitelijk ontbreekt, zoals eerder ook geconstateerd door Köbben (Kloos, 1975; Boven, 2006; Brunt, 2020). In de egalitaire gemeenschap van de Inheemsen hangt de autoriteit van het dorpshoofd sterk af van zijn voorbeeldgedrag en het vermogen om in een dergelijke bemiddeling geen druk uit te oefenen. Aantasting van de autonomie van betrokkenen verzwakt zijn positie en gezag. Straffen werkt in die zin averechts. Ook het ruimhartig toebedelen van voedsel en goederen aan de dorpsbewoners versterkt zijn gezag. Dit stemt overeen met bevindingen uit andere antropologische studies, waaruit blijkt dat in inheemse gemeenschappen het ruimhartig delen van waardevolle zaken een groot goed is en statusverhogend werkt. De 
herverdeling van welvaart voorkomt ongelijkheid; nijd en afgunst kunnen worden vermeden. ${ }^{18}$

Het herstelwerk begint bij de dader en diens familie, maar gaat feitelijk de hele lokale gemeenschap aan. De dorpsgemeenschap heeft ook een herstelrechtelijke taak die Bemmel beschreef als: 'welk werk bestaat uit het weer bij elkaar brengen van de vijandig tegenover elkaar staanden' (Bemmel, 1972: 22). Het alsnog openbaar honen van een afgestrafte wordt beschouwd als laster en is op zich een strafbaar feit. Het opnieuw oprakelen van het geschil zou het evenwicht in de gemeenschap verstoren, waarbij wraakoefening de opmaat zou zijn tot een groter conflict.

Tijdens ons onderzoek kwam regelmatig een geval van kinderontvoering met dodelijke afloop ter sprake. Justitie faalde om de dader(s) te vinden, waarna de nabestaanden ten behoeve van de waarheidsvinding en berechting een beroep hebben gedaan op de geesten. In gevallen waarbij geen bewijs geleverd kan worden maar wel een verdenking bestaat, wordt de pi-ai geraadpleegd. Deze pi-ai, de 'medicijnman' of ook 'sjamaan' genoemd, onderhoudt contacten met de geestenwereld en communiceert door middel van rituelen en gezangen. Doorgaans is de kapitein tevens pi-ai en verenigt hij wereldlijk en spiritueel leiderschap in één persoon. Ingewikkelde kwesties, waarbij mogelijk sprake is van het inzetten van kwade geesten door een verdachte, worden in de interactie met de geestenwereld beslecht. Gerechtigheid zou blijken wanneer bijvoorbeeld de verdachte plotseling ziek wordt of overlijdt. ${ }^{19}$

\subsection{Beperkte rol van het centraal gezag}

Uit de aangehaalde studies blijkt dat misdaden overwegend buiten het zicht blijven van het centraal gezag en daarmee de formele strafrechtspleging. Die bevinding stemt overeen met de visies van de door ons geïnterviewde personen. Bevestigd werd dat de meeste geschillen in eigen kring worden opgelost, zonder tussenkomst van het centraal gezag. Bij zwaardere misdaden of verdenking daarvan (moord, geweldpleging met letsel, verkrachting) en in gevallen van drugshandel en recidiverende misdadigers, wordt de politie wel op de hoogte gebracht. De politie komt naar het dorp en maakt al naargelang zij van oordeel is dat sprake is van een (vermoedelijke) misdaad wel of geen proces-verbaal op. In de tussentijd kan de traditionele geschiloplossing (krutu) ertoe leiden dat de kwestie wordt opgelost, waarna de politie kan besluiten het opgestelde proces-verbaal niet in te zenden aan het openbaar ministerie. In het uiterste geval wordt het proces-verbaal naar het parket van het openbaar ministerie in de stad gestuurd, waar wordt besloten over seponering of vervolging met daaraan verbonden voorgeleiding. Die vindt dan vaak plaats in een naburige grotere stad, zoals Albina of Nickerie. Van deze praktijk maakt Kloos voor het eerst melding na bestudering van een gedeelte van de strafdossiers uit de jaren vijftig (Kloos, 1969). Het spreekt voor zich dat door het functioneren

18 Hoebel vermeldt zelfs dat een weigerachtige rijke in vroeger tijden zelfs kon worden omgebracht, waarna zijn rijkdom alsnog naar de gemeenschap vloeide (Hoebel, 1954).

19 Bron: M. Mual, Interview met Arawaks echtpaar over de rol van de pi-ai bij conflictbeslechting. De vrouw van het echtpaar wordt door de Arawakse gemeenschap beschouwd als een pi-ai. Het interview maakt geen deel uit van het onderzoek. Paramaribo, Persoonlijke communicatie: 23 januari 2020. 
van de traditionele rechtspraak bij de Inheemsen en de grote reisafstanden voor politie en/of justitie enkel de ernstigste misdaden worden vervolgd.

\section{In hoeverre is het gewoonterecht herstelgericht?}

Onze voorlopige onderzoeksresultaten wijzen uit dat het inheemse gewoonterecht voor een groot deel herstelgerichte elementen in zich heeft. Dat stemt overeen met eerdere onderzoeksbevindingen. De Inheemsen koesteren fundamentele bezwaren tegen vrijheids- en lijfstraffen, omdat die vergelding oproepen. Bovendien vormt de lichamelijke integriteit (vrijheid) van de indiaan diens grootste goed. Daarom wordt de conflictoplossing allereerst gezocht in het onderling bespreken van de zaak en het oplossen van de gevolgen daarvan. 'Oplossen met praten', zoals een van onze respondenten het verwoordde. Overeenkomstig met deze op herstel van de lokale rechtsvrede gestoelde aanpak wordt het centrale gezag, en daarmee het moderne strafrecht, als het laatste redmiddel gezien. De Inheemse blijft zo lang mogelijk eigenaar van het conflict en beoogt het conflict zo kort mogelijk te laten duren. De lokale gezagsdrager fungeert vooral als mediator en uiteindelijk, wanneer niet tot een vergelijk wordt gekomen, als rechter/arbiter. In sommige zware gevallen is het moderne strafrecht echter het eerstaangewezen interventiesysteem. Voor de lokale gezagsdrager heeft dit als voordeel dat hij door de bestraffing uit te besteden aan het centraal gezag, zijn neutrale positie binnen de gemeenschap veilig kan stellen.

Opvallend bij deze inheemse (straf)rechtspraktijken, en wederom conform de herstelgerichte praktijken, is de rol van de gemeenschap. De begane misdaad werpt schande op de familie van de dader, diens clan en dorp en verdient daarom collectieve afkeuring. Daarbij speelt ook, net als binnen het herstelrecht, de 'proceshouding' van de overtreder een rol. Na de 'veroordeling' fungeert de gemeenschap als stimulator en bewaker van de overeengekomen herstelinspanningen. Wanneer deze worden nagekomen, wordt de dader niets meer nagedragen. De gemeenschap heeft aldus een actieve rol in de rehabilitatie van de gestrafte. De traditionele rechtspleging is - in tegenstelling tot het huidige formele strafrecht in Suriname - dan ook niet primair gericht op leedtoevoeging. Ook hier verschijnen de strafpraktijken als herstelrechtelijk georiënteerd. Gevangenissen bestaan niet in de binnenlanden en vrijheidsstraffen worden vermeden. In plaats daarvan verlaat de overtreder vrijwillig de gemeenschap: 'movement out restores harmony within' (Rivière, 1984: 84). De vraag ligt voor de hand of een zelfgekozen verhuizing zoveel verschilt van een opgelegde verbanning.

Niettemin sluiten sommigen van de door ons en anderen gesignaleerde gewoonterechtelijke reacties op misdaad niet aan op de huidige opvattingen over herstelrecht, zoals het oogluikend toestaan van eigenrichting, mits proportioneel, met uitsluiting van vergeldingsmoord of 'rammeling' met blijvend letsel, een milde lex talionis waarbij de benadeelden hun agressie kwijt kunnen. Deze oogluikend toegestane 'eigenrichting' heeft als doel om de negatieve emoties van de benadeelden te reguleren en te ventileren; het onderdrukken daarvan zou de cohesie van de ge- 
meenschap kunnen ondermijnen. ${ }^{20}$ Andere niet-herstelgerichte elementen zijn de aframmeling bij ontkennende verdachten, het opleggen van dubbele bestraffing (na traditionele berechting komt alsnog de politie in beeld en volgt berechting in de stad of andersom), het meewegen van een ontkenning als strafverzwarende factor, enzovoort.

Maar ook het publieke karakter van de krutu roept vragen op over privacy en de impact van de daarin gelegen shaming. In hoeverre is het nog re-integratief om de schaamte zo'n grote plaats te geven? ${ }^{21}$ En ook het ontbreken van een beroepsmogelijkheid kan frictie opleveren wanneer er nog onverwerkte emoties leven. Claessen en Djokarto plaatsen in dit verband een kanttekening bij de 'emotionele werkzaamheid' van de krutu: 'Bovendien dient in het kader van de werkzame aspecten te worden gewezen op het verzoeningsritueel aan het einde van de krutu: hoewel dit ritueel niet steevast betekent dat er geen negatieve emoties meer zijn, houdt het wel een bekrachtiging van de levensfilosofie in dat partijen met elkaar verder moeten en dat de krutu en al wat in het kader daarvan is gebeurd en afgesproken, dat mogelijk heeft gemaakt (Claessen \& Djokarto, 2020: 78).

\section{$6 \quad$ Besluit}

Bij de traditionele misdaadaanpak in Suriname springt vooral in het oog dat de Inheemsen het conflict zo veel mogelijk privaat proberen te houden en in der minne proberen op te lossen. Zijn delicten niet onderling op te lossen, dan komt de gewoonterechtelijke afdoening in beeld. Ook dan blijft het behouden van rust en evenwicht in de gemeenschap leidend; een te zware straf zou namelijk tot nieuwe conflicten kunnen leiden. Is de zaak door bemiddeling van de basja of granman op te lossen, zoals het geval is bij veel zwaardere delicten, zoals mishandeling, dan wordt 'opgeschaald' naar een openbare krutu. Dergelijke bijeenkomsten vinden zo snel mogelijk na de (vermeende) inbreuk plaats, onder leiding van een lokale gezagsdrager, die optreedt als mediator en rechter tegelijk, en vervolgens ook moet toezien op de naleving. Deze gezaghebbende figuur is ook regelmatig voorganger in de kerk en pi-ai. Na hoor en wederhoor en eventuele raadpleging van de ouderen volgt het oordeel. De uitkomst van dit beraad is niet punitief en veelal herstelgericht, bestaande uit het maken van excuses (in het openbaar), het vergoeden van schade (in natura), soms aangevuld met het verrichten van werkzaamheden voor de gemeenschap (vergelijkbaar met een taakstraf). De krutu wordt afgesloten met een eenvoudige maar ceremonieel krachtige handdruk en de uitkomst is onherroepelijk. De Inheemsen zijn met name gevoelig voor de beschamende kant van de 'bestraffing'. Een boete verdraagt de Inheemse beter dan gezichtsverlies. Het bij wijze van 'boetedoening' moeten schoonvegen van het dorpsplein is moeilijk te

20 Het komt voor dat het huis van de kapitein een veilig onderkomen moet bieden aan de verdachte om eigenrichting te voorkomen, als een tijdelijk huis van bewaring.

21 De antropoloog Peter Kloos noemt een geval waarin de schaamte na de misdaad zo groot was, dat het tot zelfmoord leidde (Kloos, 1972). Criminoloog John Braithwaite benadrukt de positieve werking van re-integrative shaming bij het sanctioneren van misdadig gedrag. Disintegrative shaming, het labelen en stigmatiseren van de dader, zou voorkomen moeten worden (Braithwaite, 1989). 
verdragen. Er vindt geen schriftelijke vastlegging plaats. Zoals gezegd worden zware delicten van oudsher direct bij het centraal gezag gemeld.

Het inheems gewoonterecht lijkt in de aard herstelgericht, hoewel fysieke straffen zoals ranseling volgens de orale overlevering nog wel voorkomen. Inheemse (straf) rechtspleging is een delicaat instrument om de verstoorde balans in een communaal georiënteerde samenleving zo snel mogelijk te herstellen. Het is echter zeer de vraag hoe deze gewoonterechtelijke strafpraktijken zich de komende decennia gaan ontwikkelen gezien de rappe ontsluiting van de binnenlanden.

Dat laatste brengt ons ertoe aandacht te vragen voor de noodzaak om de door ons (en anderen) beschreven inheemse (straf)rechtspraktijken meer indringend te bestuderen. Dit om te voorkomen dat de Inheemsen door de toenemende mondialisering van de Surinaamse samenleving worden geconfronteerd met voor hen 'ongewone' vormen van conflictbeslechting en sanctionering die afbreuk zouden doen aan de herstelrechtelijke elementen van het gewoonterecht die juist voor het behoud van deze inheemse gemeenschappen van waarde zijn. Wij menen dat onze onderzoeksbevindingen handvatten bieden tot overleg met en tussen lokale gezagsdragers en het centrale gezag en andersom. Dat overleg kan ook tot afstemming leiden over wanneer en hoe het centrale gezag intervenieert, ook in de nabije toekomst.

Andersom zouden gewoonterechtelijke, werkende elementen kunnen worden beproefd in de formele strafoplegging, zoals de taakstraf ín de gemeenschap waar het delict is gepleegd - dus niet in de stad of buiten de plaats waar de misdaad is begaan. Of bijvoorbeeld het inzetten van de krutu waar een collectief gedragen 'herstelplan' haalbaar is. Een dergelijke 'synthese' van gewoonterecht en formeel recht zou kunnen bestaan uit een vonnis waarin herstelgerichte sancties vrijheidsstraffen deels of geheel kunnen vervangen en daders lokaal de schade kunnen repareren. Daarenboven kan ons onderzoek aanknopingspunten bieden voor de aanpak van maatschappelijke problemen, zoals de oververtegenwoordiging van met name Marronjongeren in het jeugdstrafrecht en alternatieven voor opsluiting, zoals herstelgerichte detentie. Maar ook buiten de landsgrenzen van Suriname kan onze studie naar inheemse (straf)rechtspleging bijdragen aan een verdere ontwikkeling van een 'cultuursensitiever' herstelrecht in Nederland, waarbij bijvoorbeeld toepassing van het conferencing model een aanlokkelijk perspectief biedt.

\section{Literatuur}

Abbenhuis, M.F. (1940) Arawakken in Suriname. Enquête-materiaal voor een volkenkundige studie. Paramaribo: R.K. Missie.

Beeldsnijder, R. (1994) Om werk van jullie te hebben (diss.). Utrecht: Vakgroep Kulturele antropologie.

Bemmel, P.E. (1972) Ingie en doe Ogri? (scriptie). Paramaribo: Anton de Kom Universiteit.

Boven, K.M. (2006) Overleven in een grensgebied Veranderingsprocessen bij de Wayana in Suriname en Frans-Guyana (diss.). Amsterdam: Rozenberg Publishers.

Braithwaite, J. (1989) Crime, shame and re-integration. Cambridge: Cambridge University Press.

Brunt, L. (2021) Aan tafel met André Köbben. In: M. Schuilenburg \& D. Siegel, Significant others in de culturele criminologie. Den Haag: Boom criminologie, p. 133-138. 
Claessen, J. \& R. Djokarto (2020) Conflictbeslechting na misdaad bij de Marrons in Suriname. Tijdschrift voor Herstelrecht, 20(2), 60-79.

Hartsinck J.J. (1770) Beschryving van Guiana, of de wilde kust in Zuid-America. Geraadpleegd op: www.dbnl.org/tekst/hart038besc01_01.

Hoebel, A.E. (1954) The law of primitive man. Harvard: University Press

Hurault, J. (1968) Les indiens Wayana de la Guyane française. Structure sociale et coutume familiale. Parijs: Orstom.

Kirchner, S. (2015) Researching Indigenous Law. Legal Anthropology or Comparative Law? Norderstedt: Grin.

Kloos. P. (1969) Tribale samenleving en nationale staat: over rechtspleging bij hedendaagse Caraiben in Suriname. Sociologische Gids, 16(3), 179-186.

Kloos. P. (1971) The Maroni River Caribs of Surinam (diss.). Assen: Van Gorcum.

Kloos. P. (1975) Galibi. Een Karibendorp in Suriname. Paramaribo: Bureau Volkslectuur.

Malinowski, B. (1926) Crime and Custom in Savage Society. New York: Cambridge University Press.

Oedayrasjingh Varma, F.H.R. (1977) De strafrechtspleging in de kolonie Suriname. Amsterdam: uitgever niet bekend.

Pospisil, L.J. (1967) Kapauku Papuans and their law. Yale: Yale University.

Pronk, X. (1962) Verkenningen op het gebied van criminaliteit in Suriname. Den Haag: Martinus Nijhoff.

Rivière, P. (1984) Individual and Society in Guiana; A Comparative Study of Amerindian Social Organization. New York: Cambridge University Press.

Velanti, B. et al. (2017) Deng weti fu a twalufu lo Gaanmang meke tien na dii fu Okanisi /Aukaans wetboek. Diitabiki/Drietabbetje: Stichting 1760. Op te vragen bij de auteur dezes.

Wijnholt, M.R. (1965) Strafrecht in Suriname (diss.). Groningen: Rijksuniversiteit Groningen.

Wolbers, J. (1861) Geschiedenis van Suriname. Amsterdam: S. Emmering. 